\title{
Temporal dynamics of two species of Chaetophoraceae (Chlorophyta) in tropical streams of São Paulo State, southeastern Brazil
}

\author{
CIRO C.Z. BRANCO ${ }^{1,3}$ and ORLANDO NECCHI JUNIOR ${ }^{2}$
}

(received: April 3, 2002; accepted: January 22, 2003)

\begin{abstract}
Temporal dynamics of two species of Chaetophoraceae (Chlorophyta) in tropical streams of São Paulo State, southeastern Brazil). Temporal dynamics of the chaetophoracean green algae Chaetophora elegans (Roth) C.A. Agardh and Stigeoclonium amoenum Kützing populations was investigated biweekly during late autumn trhough early spring (April to October) in two tropical streams from northwestern São Paulo State, southeastern Brazil. Abundances of one population of each species was evaluated by the quadrat technique in terms of percent cover and frequency. The fluctuations were related to the following stream variables: temperature, turbidity, specific conductance, $\mathrm{pH}$, oxygen saturation, depth, substratum type, current velocity, irradiance and nutrients. Percent cover and frequency of $C$. elegans had lower values throughout the study period and was positively correlated to rainfall. Other correlations (i.e. positive of percent cover with depth and current velocity and negative with irradiance) were consistently found, reinforcing the strong influence of rainfall. On the other hand, percent cover and frequency of $S$. amoenum had higher values, with maximum growth from June to September. Percent cover was negatively correlated to rainfall. Results suggest the precipitation regime as the most important driving force to temporal changes in both populations, but playing different roles in each one. The gelatinous thallus of C. elegans seem to be favored by the increment of current velocity, since higher flows can improve the nutrient uptake by means of reduction in diffusion shell without promoting excessive drag force. In contrast, tufts of S. amoenum are, presumably, more exposed to drag force, and, consequently, more susceptible to mechanical damage effects due to higher current velocities.
\end{abstract}

Key words - Chaetophora, macroalgae, Stigeoclonium, stream, temporal dynamics

RESUMO - (Dinâmica temporal de duas espécies de Chaetophoraceae (Chlorophyta) em riachos tropicais do Estado de São Paulo, sudeste do Brasil). A dinâmica temporal das algas verdes Chaetophora elegans (Roth) C.A. Agardh e Stigeoclonium amoenum Kützing foi investigada bimensalmente de final do outono a início da primavera (abril a outubro) em dois riachos da região noroeste do estado de São Paulo. A abundância (cobertura percentual e freqüência) de uma população de cada espécie foi avaliada pela técnica de quadrado. A flutuação foi relacionada com as seguintes variáveis ambientais: temperatura, turbidez, condutividade específica, $\mathrm{pH}$, oxigênio dissolvido, profundidade, tipo de substrato, velocidade da correnteza, irradiância e nutrientes. Cobertura percentual e freqüência de C. elegans foram baixas durante todo o período e correlacionaram-se positivamente com precipitação pluviométrica. Outras correlações (positiva de cobertura percentual com profundidade e velocidade da correnteza e negativa com irradiância) foram consistentemente encontradas, reforçando a forte influência da precipitação. Cobertura percentual e freqüência de $S$. amoenum foram altas, com valores máximos entre junho e setembro. Cobertura percentual foi negativamente correlacionada com precipitação. Os resultados sugerem o regime de precipitação pluviométrica como a mais importante força influenciadora das mudanças temporais em ambas populações, entretanto, desempenhando diferentes papéis em cada uma delas. $\mathrm{O}$ talo gelatinoso de $C$. elegans parece ser favorecido por um aumento da velocidade da correnteza, pois fluxos mais intensos levariam a uma maior eficiência na aquisição de nutrientes, devido à redução no tamanho da concha de difusão sem, entretanto, provocar atrito excessivo entre a planta e a massa d'água. Em contraste, tufos de S. amoenum são, presumivelmente, mais expostos e, conseqüentemente, mais susceptíveis à força mecânica gerada pelo aumento da velocidade da correnteza.

Palavras-chave - Chaetophora, dinâmica temporal, macroalgas, riacho, Stigeoclonium

\section{Introduction}

Structure of stream macroalgal communities can be affected by specific environmental variables, such

1. Universidade Estadual do Centro-Oeste, Departamento de Biologia, Núcleo de Pesquisas Ambientais - NPA, Caixa Postal 730, 85015-430 Guarapuava, PR, Brazil.

2. Universidade Estadual Paulista, Departamento de Zoologia e Botânica, Rua Cristovão Colombo, 2265, 15054-000 São José do Rio Preto, SP, Brazil.

3. Corresponding author: czbranco@unicentro.br as current velocity, temperature, substratum type, light, grazing and water chemistry (Sheath et al. 1989, Everitt \& Burkholder 1991, Uehlinger 1991, Rosemond \& Brawley 1996). Several studies have showed that most of these parameters vary seasonally and are related to the fluctuations in stream macroalgal communities (e.g. Pringle 1990, Sheath \& Hambrook 1990, Everitt \& Burkholder 1991, Pfister 1993, Rosemond 1994, Borchardt 1996, DeNicola 1996, Hill 1996). 
The green algal family Chaetophoraceae is a well represented taxonomic group in stream macroalgal communities worldwide, mainly by species of Chaetophora and Stigeoclonium (Holmes \& Whitton 1981, Entwisle 1989, Biggs 1990, Sheath \& Cole 1992, Branco \& Necchi Junior 1996a, 1997, Necchi Junior et al. 2000). However, available information concerning temporal distribution of these green algae is still scarce, particularly for tropical regions. Despite the high frequency of occurrence in stream habitat communities, temporal analysis of individual species of Chaetophoraceae are virtually absent in literature.

Seasonal data on populations of Chaetophoraceae are mostly reported in broader studies focusing on the entire macroalgal communities. Some recent investigations are relevant in this context, including few carried out in Brazilian lotic ecosystems, such as Necchi Junior et al. (1991), Necchi Junior \& Pascoaloto (1993) and Branco \& Necchi Junior (1997). Similarly, specific seasonal studies with members of Chaetophoraceae in running waters are few. Entwisle (1989) described the seasonal variation in abundance of the CladophoraStigeoclonium communities in two urban creeks from Australia, showing that the growth pattern of these algae are distinct year round. Rosemond \& Brawley (1996) found that the species-specific characteristics explain the persistence of Stigeoclonium tenue (C.A. Agardh) Kützing in a woodland stream from Tennessee, USA.

Considering the scarcity of information on temporal dynamics of Chaetophoracean species in stream environments, this study was taken aiming to describe the temporal variation patterns of Chaetophora elegans and Stigeoclonium amoenum populations, in two streams from the northwest region of São Paulo State, southeastern Brazil.

\section{Material and methods}

The study was carried out in two tropical streams from the northwest region of São Paulo State, southeastern Brazil. The population of Chaetophora elegans (Roth) C.A. Agardh was sampled in Talhadinho Stream, a third-order stream segment, with continuous rocky substratum, located in São José do Rio Preto $\left(20^{\circ} 43^{\prime} \mathrm{S}\right.$ and $\left.49^{\circ} 13^{\prime} \mathrm{W}\right)$. The population of Stigeoclonium amoenum Kützing was analyzed in Borá Stream, also a third-order stream segment with predominantly rocky substratum, located in the municipality of Cedral $\left(20^{\circ} 58^{\prime} \mathrm{S}\right.$ and $\left.49^{\circ} 25^{\prime} \mathrm{W}\right)$. The sampling sites were visited biweekly during the typical growth period of the macroalgal communities in this region (Necchi Junior \& Pascoaloto 1993, Branco \& Necchi Junior 1997), extending from late autumn
(28 May - Talhadinho Stream and 26 April - Borá Stream) to early spring (15 October - Talhadinho and 31 October - Borá Stream) in 1996. This sampling period was mandatory due to low abundance, or even lack of plants, during the remaining of the year not allowing observations and collections for the purposes of this study.

The sampling sites consisted of a $10 \mathrm{~m}$ length stream segment (Sheath \& Burkholder 1985). The abundance of the populations were estimated by means of the quadrat technique (Necchi Junior et al. 1995a). Sampling units were circles of $25 \mathrm{~cm}$ in diameter $\left(\right.$ area $\left.=0.05 \mathrm{~m}^{2}\right)$; this shape was adopted to reduce the edge effect (Krebs 1989). The size of sampling units was chosen on the basis of preliminary tests and a previous investigation (Necchi Junior et al. 1995b). Twenty sampling units were distributed in pairs at 10 equally spaced intervals along the stream segment, resulting in a total sampling area of $1 \mathrm{~m}^{2}$ in each collecting date. Within the sampling units, algal percent cover on the substratum was estimated visually (Necchi Junior 1993, Branco \& Necchi Junior 1998) with a Plexiglas viewbox (bottom surface ca $175 \mathrm{~cm}^{2}$ ). We tested the accuracy of percent cover of Stigeoclonium amoenum against ash-free dry-weight in 15 sampling units consisting of circles $10 \mathrm{~cm}$ in diameter (area ca. $79 \mathrm{~cm}^{2}$ ) and they proved to be positively correlated $(\mathrm{r}=0.69, \mathrm{p}<0.01)$. Necchi Junior \& Branco (1998) also described, to the red alga Batrachospermum delicatulum (Skuja) Necchi \& Entwisle, positive correlation $(\mathrm{r}=0.37-0.54$, $\mathrm{p}<0.01)$ among visual estimation and two usual destructive techniques (ash-free dry-weight and chlorophyll $a$ ). Therefore, this parameter proved to be reliable for the purpose of this study. Frequency of occurrence was also calculated, considering the number of sampling units with algal thallus to the total units sampled.

Ten plants were randomly collected along the stream segment for morphometric analysis on each sampling date. Samples were preserved in $4 \%$ formaldehyde (Branco \& Necchi Junior 1996a) for microscopic observation. The randomization of sites for algal collection was based on the position indicated by the collector's watch hand at predetermined time intervals (Necchi Junior et al. 1997).

Specimens collected within quadrats were measured for the following morphometric characters: Chaetophora elegans, colony diameter, cell length and diameter (main axis) and apical branch number; Stigeoclonium amoenum, plant length, cell length and diameter of the main axis and lateral branches cell length and diameter. These characters were chosen according to a previous study (Branco \& Necchi Junior 1998). Measurements were made in replicates of 12 for all morphometric characters.

The following environmental variables were measured: water temperature, specific conductance, turbidity, $\mathrm{pH}$ and dissolved oxygen, with Horiba U-10 water checker, equipped with a multiple probe from a water sample collected in midstream segments at 12:00 $\pm 1 \mathrm{~h}$. Current velocity was measured by using a General Oceanics 2030R mechanical 
flowmeter immediately below the water surface, whereas irradiance was determined with a Li-Cor LI-189 quantameter and a Li-Cor LI-193SA spherical quantum sensor at the stream bottom. Nutrients (except total nitrogen and phosphorous) were analyzed with a Horiba F-24 ion meter and Orion ion selective electrodes (ammonia, nitrate, nitrite, calcium and potassium) from a water sample collected at the midpoint of sampling sites. Total $\mathrm{N}$ an $\mathrm{P}$ were determined according to the technique described by Valderrama (1981). Current velocity, irradiance and depth (with a rule) were measured at the center of each sampling unit. Substratum type (according to particle size classes given by Gordon et al. 1992) was also annotated. Rainfall data for the closest locality of the sampling site were provided by the Regional Division of the Secretary of Agriculture, São Paulo State (figure 1). Numerical data were submitted to the following statistical analyses (Sokal \& Rohlf 1981): Analysis of Variance (ANOVA, one way), Pearson's product-moment correlation coefficient and multiple regression. Tests were performed by using the Minitab statistical package (Ryan et al. 1985).
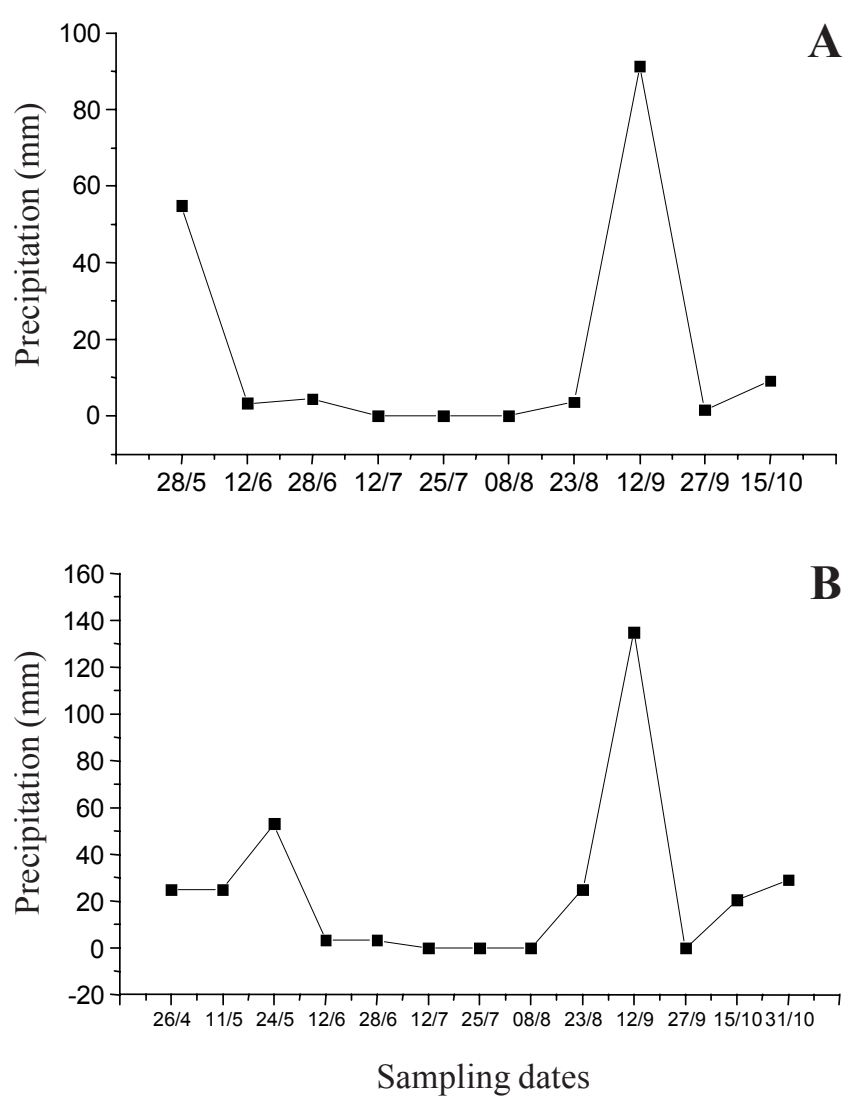

Figure 1. Temporal variation of pluviometric precipitation in Talhadinho Stream (A) and Borá River (B) throughout the study period.

\section{Results}

Chaetophora elegans (Roth) C.A. Agardh Environmental data (figures 2-3) are described only for the variables that revealed some relationship with biological parameters of the population studied. Temperature varied considerably throughout the study period $\left(17.1-25.5^{\circ} \mathrm{C}, 20.7 \pm 2.7\right.$, mean \pm one standarddeviation), with the lowest values in early winter and the highest during early spring. It was positively correlated with irradiance $(\mathrm{r}=0.73, \mathrm{p}<0.01)$. Specific conductance varied from 38.6 to $89.2 \mu{\mathrm{S} . \mathrm{cm}^{-1}}^{-1}(68.3 \pm$ 15.8) and revealed a similar pattern with temperature $(\mathrm{r}=0.86, \mathrm{p}<0.001)$. Dissolved oxygen had values in the range of 3.9-6.3 mg. $\mathrm{L}^{-1}$ and was negatively correlated with temperature $(\mathrm{r}=-0.73, \mathrm{p}<0.01)$. Irradiance was high throughout the period, ranging from 1,150 to $2,435 \mu \mathrm{mol} \cdot \mathrm{m}^{-2} \cdot \mathrm{s}^{-1}(1,765 \pm 705)$, except for extremely low values on 28 June $\left(53 \mu \mathrm{mol} . \mathrm{m}^{-2} . \mathrm{s}^{-1}\right)$, due to rainy conditions. It was negatively correlated with current velocity $(r=-0.84, p<0.001)$. Depth was low varying from 5.4 to $7.7 \mathrm{~cm}(6.0 \pm 0.9)$, with lower values in the peak of winter. Current velocity tended to decrease along the period $\left(39-74 \mathrm{~cm} \cdot \mathrm{s}^{-1}, 48 \pm 11\right)$, except for a peak on 28 June. The potassium concentration showed a relatively narrow variation, ranging from 15.5 to $20.0 \mathrm{mg} . \mathrm{L}^{-1}(16.6 \pm 1.3)$, except for a peak on 28 June, with a slight increase towards the end of the period. The nitrate concentration, showed a similar pattern with potassium, with narrow variation (9.6-10.7 $\mu \mathrm{g} . \mathrm{L}^{-1}, 10.3$ $\pm 0.2)$.

The population of Chaetophora elegans varied significantly throughout the study period in terms of percent cover $(F=3.5, p<0.001)$ (figure 4$)$, with very low values, ranging from 0 to $0.9 \%(0.4 \pm 0.3)$. It was positively correlated with frequency $(\mathrm{r}=0.85, \mathrm{p}<0.001)$ and precipitation $(\mathrm{r}=0.58, \mathrm{p}<0.05)$ and negatively correlated with nitrate $(r=-0.74, p<0.01)$ and potassium $(\mathrm{r}=-0.58, \mathrm{p}<0.05)$. Multiple regression analysis revealed that precipitation, depth, current velocity and irradiance, were conjointly responsible for $68 \%$ in percent cover variation of $C$. elegans population. Correlations tests of $C$. elegans abundance with environmental variables performed to each sampling date individually showed consistent results. Percent cover was positively correlated with depth and current velocity in $33 \%$ and $22 \%$ of the sampling dates, respectively, and negatively with irradiance in $33 \%$ of samplings.

Frequency showed the same seasonal pattern of abundance, with low values during the entire period, from 0 to $60 \%(29 \pm 22)$ (figure 4$)$. Frequency was 
negatively correlated with potassium $(\mathrm{r}=0.67, \mathrm{p}<0.05)$.

The morphometric characters of Chaetophora elegans population exhibited the following significant correlations: cell length was positively correlated with current velocity $(\mathrm{r}=0.72, \mathrm{p}<0.01)$ and negatively with irradiance $(\mathrm{r}=0.82, \mathrm{p}<0.01)$.

Stigeoclonium amoenum Kützing - Environmental data (figures 5-6) revealed a considerable fluctuation for most
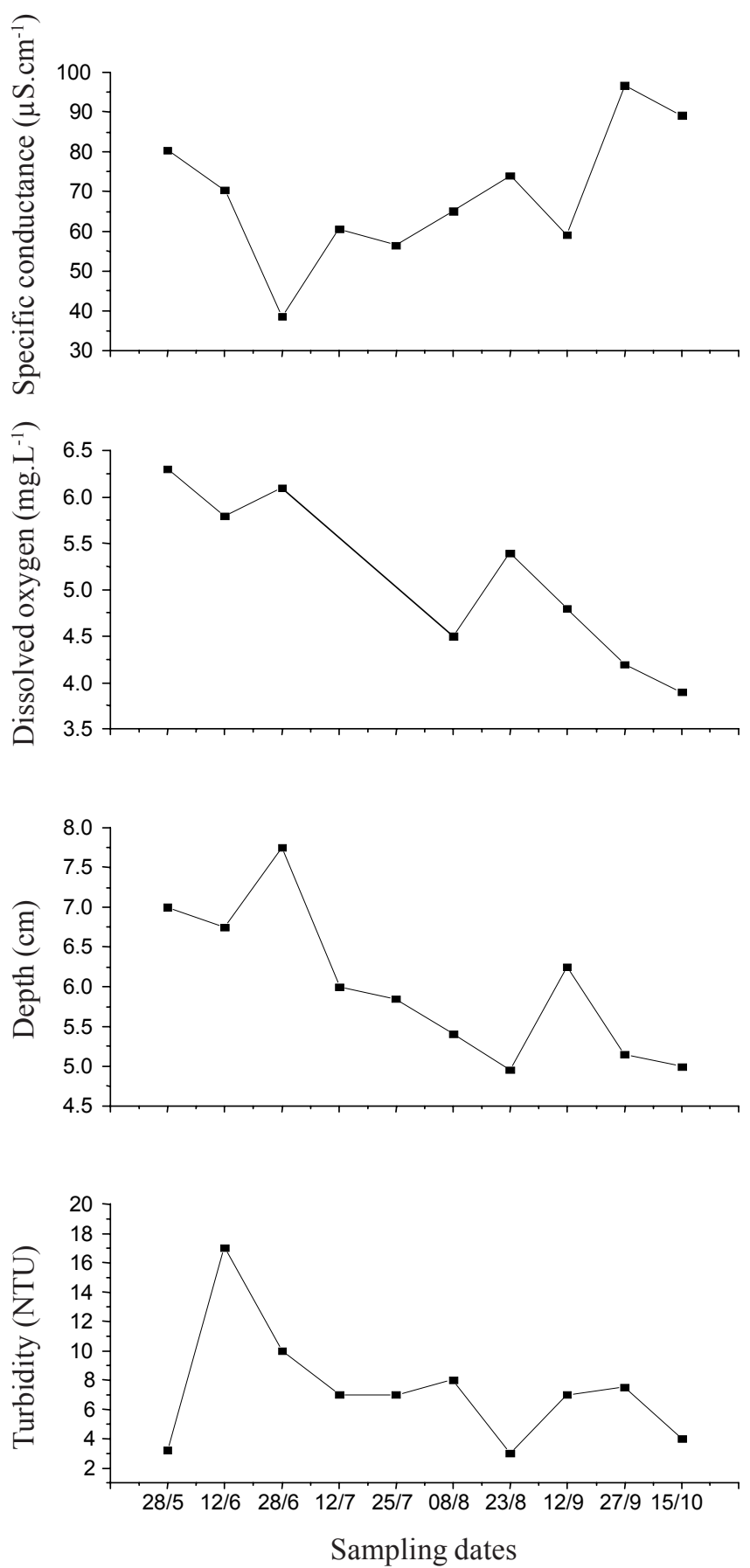

variables. Temperature had values ranging from 16.0 to $24.3{ }^{\circ} \mathrm{C}(19.6 \pm 0.7)$, with lowest values during JuneAugust (winter peak) and the highest in SeptemberOctober (early spring). It was positively correlated with specific conductance $(\mathrm{r}=0.93, \mathrm{p}<0.001)$. Specific conductance had values in the range of 74 to $145 \mu \mathrm{S} . \mathrm{cm}^{-1}$ (103 \pm 7.3$)$, with lower values during the winter period (dry season). Values of dissolved oxygen fluctuated from
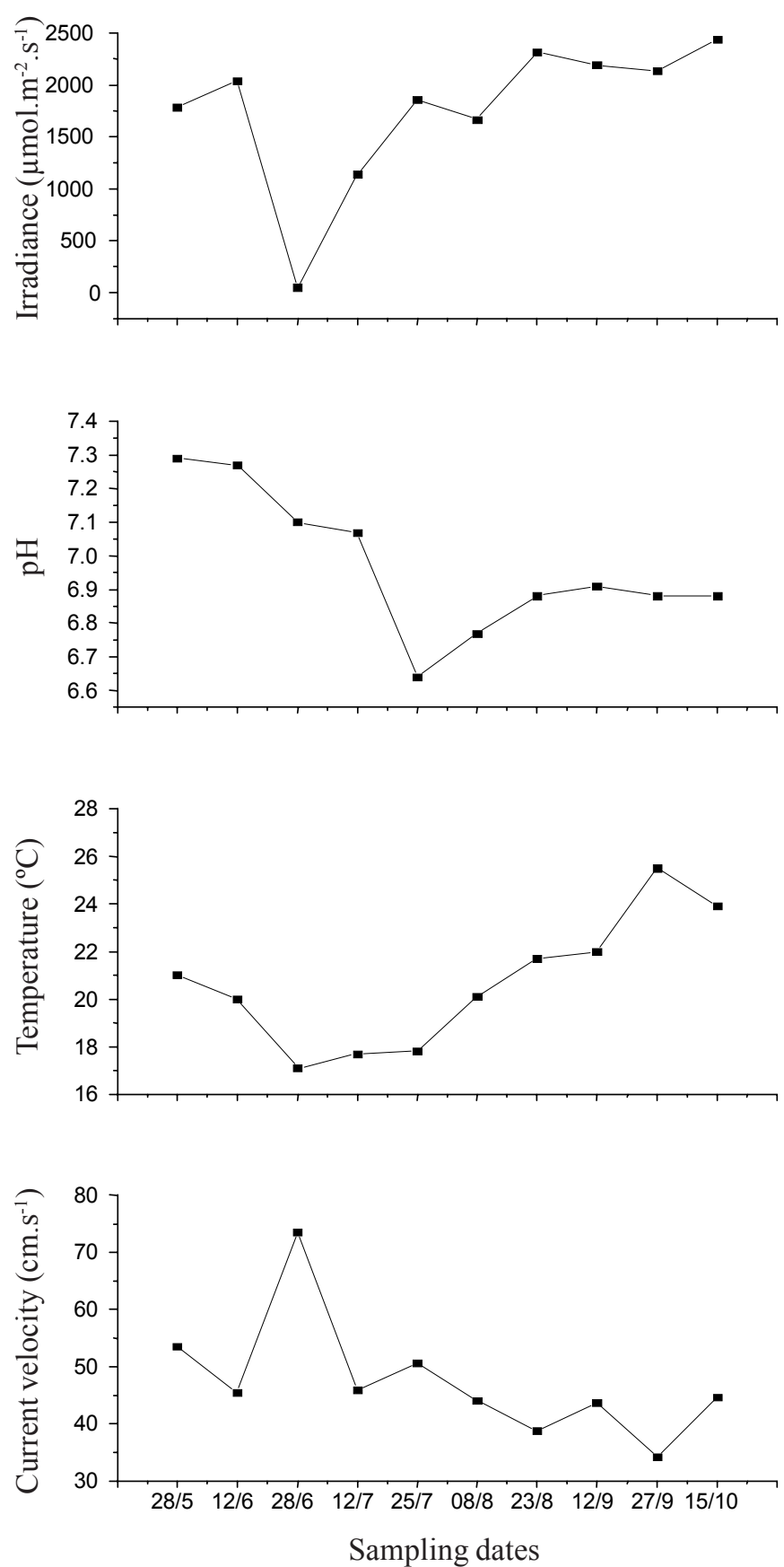

Figure 2. Temporal variation of stream variables in Talhadinho Stream throughout the study period. 
4.2 to $6.9 \mathrm{mg} . \mathrm{L}^{-1}(5.5 \pm 0.3)$ and were positively correlated with current velocity $(r=0.57, \mathrm{p}<0.05)$. Irradiance was high throughout the study period, with values ranging from 528 to $1,421 \mu \mathrm{mol} \cdot \mathrm{m}^{-2} \cdot \mathrm{s}^{-1}(1,039 \pm$ $397)$, except on 28 June $\left(85 \mu \mathrm{mol} . \mathrm{m}^{-2} \cdot \mathrm{s}^{-1}\right)$ due to rainy conditions. Depth varied from 19.1 to $25.6 \mathrm{~cm}(21.8 \pm$ $0.4)$ and was positively correlated with precipitation $(\mathrm{r}=$ $0.60, \mathrm{p}<0.05)$. Current velocity had higher values at the beginning and end of samplings, and lower values in the peak of dry season (40-66 cm.s. $\left.{ }^{-1}, 50 \pm 7\right)$. ANOVA showed significant differences for irradiance, depth and current velocity $(\mathrm{F}=8.9-43.3, \mathrm{p}<0.001)$.

The percent cover of Stigeoclonium amoenum population varied significantly throughout the sampling period $(\mathrm{F}=13.9, \mathrm{p}<0.001)$, ranging from $3.7 \%$ to $33.5 \%(13.5 \pm 10.6)$ (figure 7$)$. It was
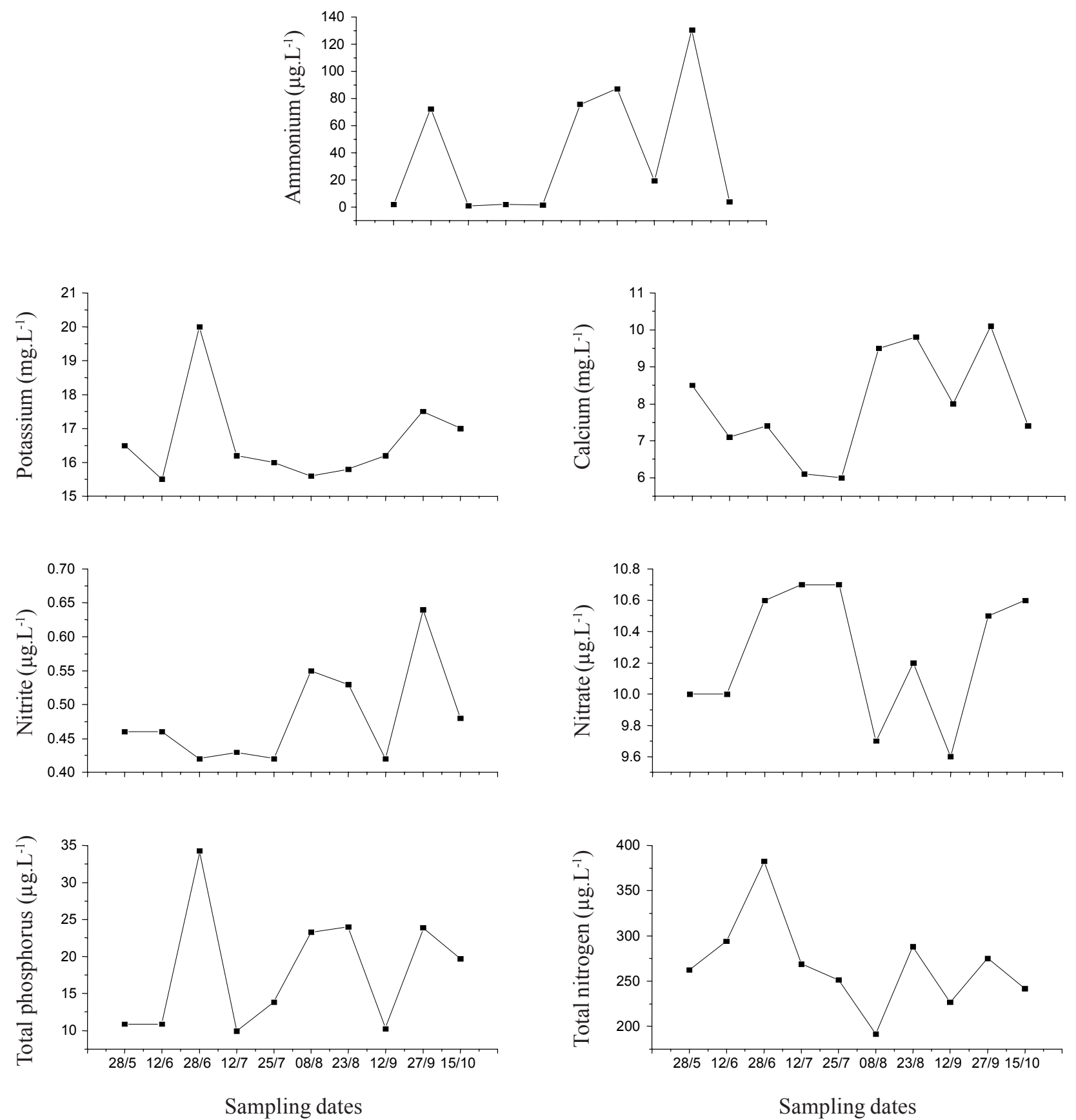

Figure 3. Temporal variation of nutrients in Talhadinho Stream throughout the study period. 

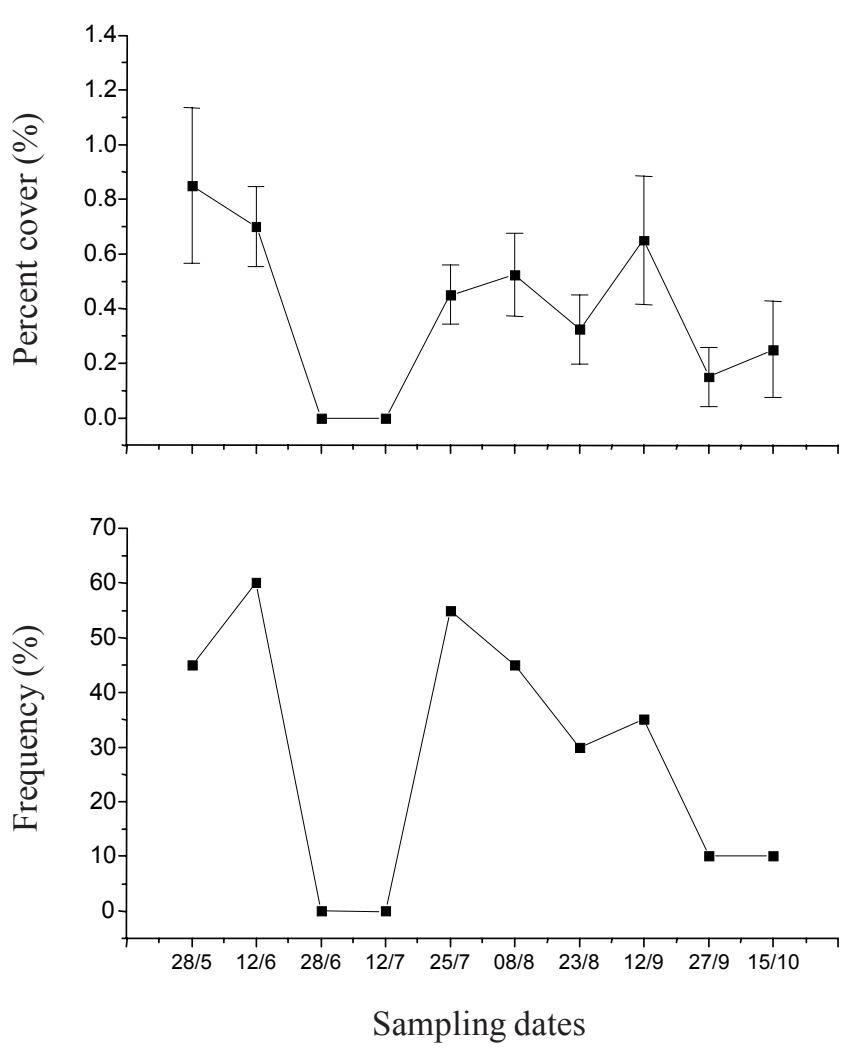

Figure 4. Temporal variation of percent cover and frequency of Chaetophora elegans in Talhadinho Stream throughout the study period.

positively correlated with frequency $(\mathrm{r}=0.68$, $\mathrm{p}<0.01)$ and negatively with precipitation $(\mathrm{r}=-0.53$, $\mathrm{p}<0.05)$. Multiple regression revealed that precipitation, current velocity, depth and irradiance accounted for $42.1 \%$ of the variation in percent cover of $S$. amoenum. Percent cover was positively correlated with proportion of boulders and macrophyte in substrata of $15 \%$ and $31 \%$ of the sampling dates, respectively, whereas in $31 \%$ of samplings a negative correlation with sand-clay substratum was found.

Frequency had a slight variation throughout the study period with a clear tendency to high values $(85-100 \%, 92 \pm 6.3$, figure 7$)$. It was negatively correlated with temperature $(r=-0.75, p<0.01)$ and specific conductance $(r=-0.64, p<0.05)$.

No significant correlation of percent cover and frequency of Stigeoclonium amoenum with nutrients was found.

The morphometric characters of Stigeoclonium amoenum population showed the following significant correlations: main axes cell diameter and length were negatively correlated with current velocity $(\mathrm{r}=-0.65$, $\mathrm{p}<0.05$ and $\mathrm{r}=-0.67, \mathrm{p}<0.01$, respectively) and positively with irradiance $(\mathrm{r}=0.68, \mathrm{p}<0.01$ and $\mathrm{r}=0.58$, $\mathrm{p}<0.05$, respectively).

\section{Discussion}

The temporal dynamics of Chaetophora elegans was characterized by very low values of percent cover and frequency throughout sampling period. Similar seasonal data were previously reported (Necchi Junior \& Pascoaloto 1993), suggesting a consistent pattern for this species in lotic habitats of this region. Despite the low values of percent cover of $C$. elegans, results indicated a possible influence of precipitation regime, and its effects, on the population studied, suggesting that this variable was the driving force most closely related with temporal variations of species abundance. In support to this view, some correlations were consistently observed throughout the sampling period (e.g., positive with depth and current velocity; negative with irradiance), corroborating the influence of precipitation on abundance of $C$. elegans population.

Precipitation regime has been often described as an important factor of seasonal changes of macroalgal communities in lotic ecosystems from tropical regions in Brazil (Necchi Junior et al. 1991, Necchi Junior \& Pascoaloto 1993, Branco \& Necchi Junior 1997). Branco \& Necchi Junior (1997) ascribed the capacity to provoke change in local environmental conditions and, consequently, the algal communities to the rainfall in three tropical drainage systems. Variations in the precipitation regime could cause indirect effects, mainly related to the current velocity pattern. Higher values of current velocity promote two opposite major forces acting on algal communities (Stevenson 1996): a) a positive force of stimulation related with increase in the nutrients uptake; b) a negative drag force tending to brush the plants downstream. The gelatinous thallus of Chaetophora elegans seems to be stimulated by a moderate increase in current velocity that would promote a reduction of diffusion shell and, consequently, increase nutrient uptake. On the other hand, the drag force would be minimized because the filaments are protected from direct mechanical effects of water flow for being immersed in a mucilaginous matrix.

Branco \& Necchi Junior (1998) investigated microhabitat distribution and niche width of two populations of Chaetophora elegans from São Paulo State. Narrow microhabitat conditions and smaller niche width of both populations were related to the low abundance in streams from São Paulo State. In addition, moderate to high values of current velocity were 

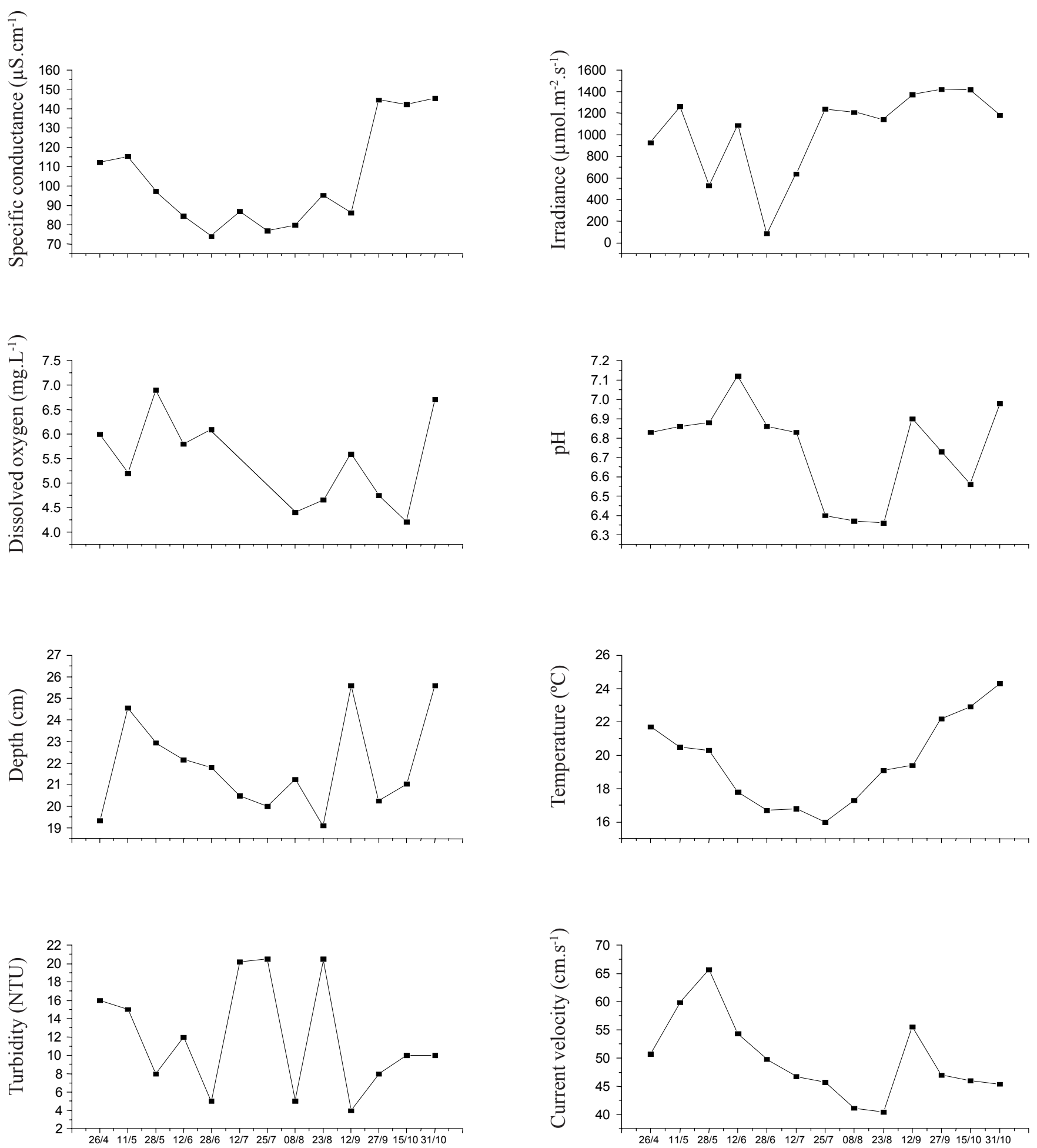

Sampling dates

Sampling dates

Figure 5. Temporal variation of stream variables in Borá Stream throughout the study period. 

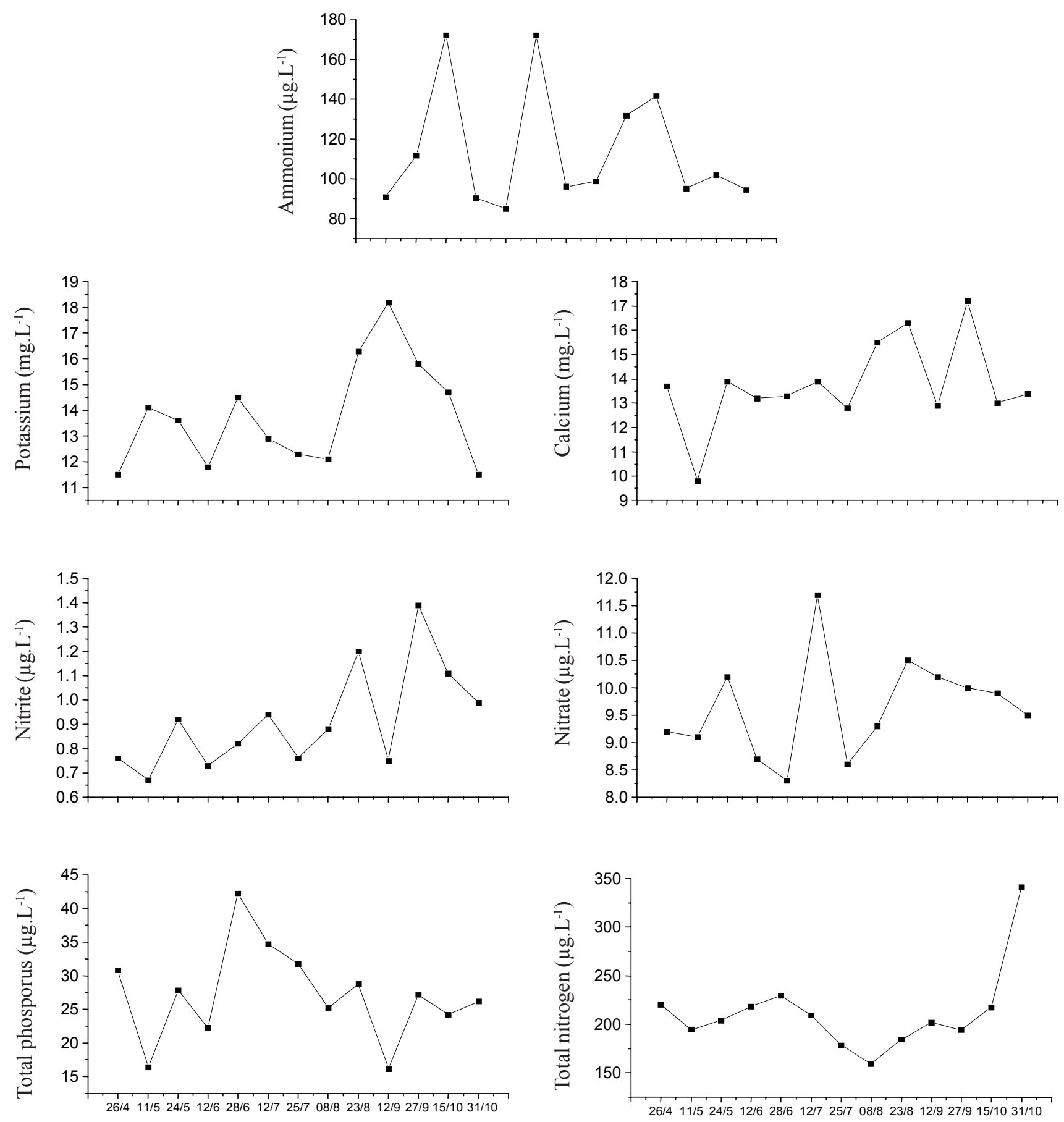

Sampling dates

Sampling dates

Figure 6. Temporal variation of nutrients in Borá Stream throughout the study period. 

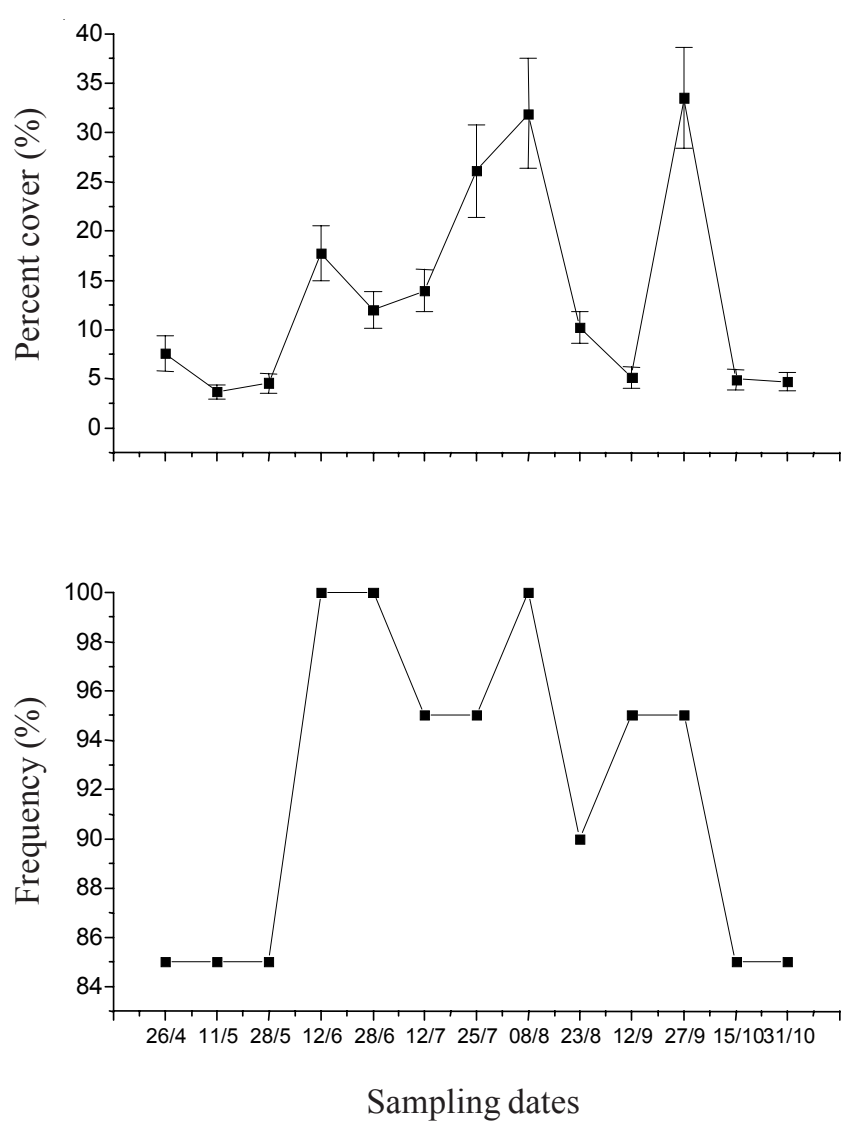

Figure 7. Temporal variation of percent cover and frequency of Stigeoclonium amoenum in Borá Stream throughout the study period.

suggested as one of the most favorable microhabitat conditions for development of this species. Therefore, the typical pattern of low abundance of C. elegans found in several streams from São Paulo State (Necchi Junior et al. 1995a, Branco \& Necchi Junior 1996b, 1997, 1998), also found in this study, can be associated to a combination of microhabitat conditions and seasonal fluctuations determined by the rainfall regime.

The peak of percent cover and frequency of Stigeoclonium amoenum population occurred during driest season (June to September) in studied area. The percent cover of $S$. amoenum was negatively correlated to precipitation, indicating a different influence on the population than that observed in Chaetophora elegans. The increase in current velocity induces a higher mechanical pressure on $S$. amoenum plants and, consequently, damage effects. This negative influence is specially important to this species, which has no specific morphological adaptation to avoid drag force.

Correlations observed within sampling dates revealed that substratum type can influence the percent cover of Stigeoclonium amoenum. Macrophytes and boulders had consistent positive correlations with abundance in several sampling dates, revealing the association to more stable substrata with the population establishment and maintenance. Coherently, negative correlations were found of percent cover with an unstable substratum (sand-clay). Thus, the effects promoted by precipitation on substratum composition altering population's abundance are best viewed as mechanical interactions related to plants attachment than as ecophysiological features.

Entwisle (1989) described the extensive growth of Stigeoclonium during winter and spring, covering most submerged substrata, but no development into long massive tufts as in Cladophora during summer. Our data indicated a similar seasonal pattern of growth, with the most expressive biomass during winter, but the possible causes were sharply different. The most important driving factors pointed out by Entwisle (1989) were nutrient concentration (such as nitrogen and phosphorous), substrata availability and a higher diffusion gradient promoted by rising water levels, and consequently, faster flowing, helping Stigeoclonium to out compete Cladophora in early and late season growth.

Rosemond \& Brawley (1996) reported that Stigeoclonium tenue (C.A. Agardh) Kützing had lower photosynthetic capacity than other algae at high environmental irradiance and low nutrient levels, indicating low competitive capacity under these specific conditions. In addition, the authors suggested that Stigeoclonium may also become relatively more susceptible to herbivore when irradiance is increased. No direct correlation was observed among abundance of Stigeoclonium amoenum and irradiance or nutrients in this study, whereas grazing effects have not been examined. However, there was no evidence of expressive growth of insect larvae (or other macroinvertebrates) in the streams analyzed in this study and, thus, no major influence on Chaetophoracean species abundance is expected.

A microhabitat investigation (Branco \& Necchi Junior 1998) indicated Stigeoclonium amoenum (as $S$. helveticum Vischer) as a generalist species, being able to support a wide range of microhabitat conditions. In addition, results of this study suggest that $S$. amoenum has also high tolerance to temporal variations.

Morphometric variation in Chaetophora elegans and Stigeoclonium amoenum plants examined throughout this study also showed differences between these Chaetophoracean species. Plants of C. elegans exhibited weak correlations to morphometric characteristics and environmental parameters. In 
contrast, many correlations were found with morphometric data and environmental variables in plants of $S$. amoenum, suggesting wide morphological plasticity. Therefore, plants of $S$. amoenum are presumably well adapted to the fluctuations in the surrounding environment by branch reconfiguration (Sheath \& Hambrook 1988). Thus, it takes advantage in using more efficiently the environmental resources for their ecological success in lotic ecosystems.

Acknowledgements - This study was supported by a Fapesp grant-in-aid (95/2758-8) to ONJ and CNPq research grants to CCZB (520257/01-4) and ONJ (520551/96-6). We are grateful to Maria Helena Carabolante for help in the laboratory analyses.

\section{References}

BIGGS, B.J.F. 1990. Periphyton communities and their environments in New Zealand rivers. New Zealand Journal of Marine and Freshwater Research 24:367-386.

BORCHARDT, M.A. 1996. Nutrients. In Algal ecology; freshwater benthic ecosystems (R.J. Stevenson, M.L. Bothwell \& R.L. Lowe, eds.). Academic Press, San Diego, p.84-227.

BRANCO, C.C.Z. \& NECCHI JUNIOR, O. 1996a. Survey of stream macroalgae of eastern Atlantic Rainforest of São Paulo State, southeastern Brazil. Archiv für Hydrobiologie 80:35-57.

BRANCO, C.C.Z. \& NECCHI JUNIOR, O. 1996b. Distribution of stream macroalgae in the eastern Atlantic Rainforest of São Paulo State, southeastern Brazil. Hydrobiologia 333:139-150.

BRANCO, C.C.Z. \& NECCHI JUNIOR, O. 1998. Microhabitat and morphometric variation of two Chaetophoracean (Chaetophorales, Chlorophyta) species in tropical streams of southeastern Brazil. Phycological Research 46:169-174.

BRANCO, L.H.Z. \& NECCHI JUNIOR, O. 1997. Seasonality of macroalgae in three tropical drainage basins in São Paulo State, southeastern Brazil. Archiv für Hydrobiologie 141:75-91.

DENICOLA, D.M. 1996. Periphyton responses to temperature at different ecological levels. In Algal ecology; freshwater benthic ecosystems (R.J. Stevenson, M.L. Bothwell \& R.L. Lowe, eds.). Academic Press, San Diego, p.150-181.

ENTWISLE, T.J. 1989. Phenology of the CladophoraStigeoclonium community in two urban creeks of Melbourne. Australian Journal of Marine and Freshwater Research 40:471-489.

EVERITT, D.T. \& BURKHOLDER, J.M. 1991. Seasonal dynamics of macrophyte communities from a stream flowing over granite flatrock in North Carolina, USA. Hydrobiologia 222:159-172.
GORDON, N.D., MCMAHON, T.A. \& FINLAYSON, B.L. 1992. Stream hydrology; an introduction for ecologists. John Wiley \& Sons, Chichester.

HILL, W.R. 1996. Effects of light. In Algal ecology; freshwater benthic ecosystems (R.J. Stevenson, M.L. Bothwell \& R.L. Lowe, eds.). Academic Press, San Diego, p.121-148.

HOLMES, N.T.H. \& WHITTON, B.A. 1981. Phytobentos of River Tess and its tributaries. Freshwater Biology 11:139-163.

KREBS, C.J. 1989. Ecological methodology. Harper and Row, New York.

NECCHI JUNIOR, O. 1993. Distribution and seasonal dynamics of Rhodophyta in the Preto River basin, southeastern Brazil. Hydrobiologia 250:81-90.

NECCHI JUNIOR, O. \& BRANCO, C.C.Z. 1998. Phenology of a dioecius population of Batrachospermum delicatulum (Batrachospermales, Rhodophyta) in a stream from southeastern Brazil. Phycological Research 47:169-174.

NECCHI JUNIOR, O., BRANCO, C.C.Z., SIMÕES, R.C.G. \& BRANCO, L.H.Z. 1995a. Distribution of stream macroalgae in northwest region of São Paulo State, southeastern Brazil. Hydrobiologia 299:219-230.

NECCHI JUNIOR, O., BRANCO, L.H.Z. \& BRANCO, C.C.Z. 1995b. Comparison of three techniques for estimating periphyton abundance in bedrock streams. Archiv für Hydrobiologie 134:393-402.

NECCHI JUNIOR, O., BRANCO, C.C.Z. \& BRANCO, L.H.Z. 2000. Distribution of stream macroalgae in São Paulo State, southeastern Brazil. Algological Studies 97:43-57.

NECCHI JUNIOR, O., DIP, M.R. \& GÓES, R.M. 1991. Macroalgae of a stream in southeastern Brazil: composition, seasonal variation and relation to physical and chemical variables. Hydrobiologia 213:241-250.

NECCHI JUNIOR, O. \& PASCOALOTO, D. 1993. Seasonal dynamics of macroalgal communities in the Preto River basin, São Paulo, southeastern Brazil. Archiv für Hydrobiologie 129:231-252.

NECCHI JUNIOR, O., PASCOALOTO, D., BRANCO, C.C.Z. \& BRANCO, L.H.Z. 1997. Stream macroalgae flora from the northwest region of São Paulo State, southeastern Brazil. Archiv für Hyrobiologie 84:91-112.

PFISTER, P. 1993. Seasonality of macroalgal distribution pattern within the reach of a gravel stream (Isar, Tyrol, Austria). Archiv für Hydrobiologie 129:89-107.

PRINGLE, C.M. 1990. Nutrient spatial heterogeneity: effects on the community structure, physiognomy and diversity stream algae. Ecology 71:905-920.

ROSEMOND, A.D. 1994. Multiple factors limit seasonal variation in periphyton in a forest stream. Journal of the North American Benthological Society 13:333-344.

ROSEMOND, A.D. \& BRAWLEY, S.H. 1996. Species-specific characteristics explain the persistence of Stigeoclonium tenue (Chlorophyta) in a woodland stream. Journal of Phycology 32:54-63. 
RYAN, B.F., JOINER, B.L. \& RYAN, T.A. 1985. Minitab handbook. Duxbury Press, Boston.

SHEATH, R.G. \& BURKHOLDER, J. 1985. Characteristics of softwater stream in Rhode Island. II: Composition and seasonal dynamics of macroalgae communities. Hydrobiologia 128:109-118.

SHEATH, R.G. \& COLE, K.M. 1992. Biogeography of stream macroalgae in North America. Journal of Phycology 28:448-460.

SHEATH, R.G. \& HAMBROOK, J.A. 1988. Mechanical adaptation to flow in freshwater red algae. Journal of Phycology 24:107-111.

SHEATH, R.G. \& HAMBROOK, J.A. 1990. Freshwater ecology. In Biology of red algae (K.M. Cole \& R.G. Sheath, eds.). Cambridge University Press, Cambridge, p.423-453.
SHEATH, R.G., HAMILTON, P.B., HAMBROOK, J.A. \& COLE, K.M. 1989. Stream macroalgae of eastern boreal forest region of North America. Canadian Journal of Botany 67:3553-3562.

SOKAL, R.R. \& ROHLF, F.J. 1981. Biometry. W.H. Freeman, New York.

STEVENSON, R.J. 1996. The stimulation and drag force of current. In Algal ecology; freshwater benthic ecosystems (R.J. Stevenson, M.L. Bothwell \& R.L. Lowe, eds.). Academic Press, San Diego, p.321-340.

UEHLINGER, U. 1991. Spatial and temporal variability of periphyton biomass in a prealpine river (Necker, Switzerland). Archiv für Hydrobiologie 123:219-237.

VALDERRAMA, J.C. 1981. The simultaneous analysis of total nitrogen and phosphorus in natural waters. Marine Chemistry 10:109-122. 